\title{
Józef Łupiński
}

\section{Dziekani okręgowi w diecezji wigierskiej i diecezji augustowskiej czyli sejneńskiej}

Prawo Kanoniczne : kwartalnik prawno-historyczny 49/1-2, 195-226

2006

Artykuł został opracowany do udostępnienia w internecie przez Muzeum Historii Polski w ramach prac podejmowanych na rzecz zapewnienia otwartego, powszechnego i trwałego dostępu do polskiego dorobku naukowego i kulturalnego. Artykuł jest umieszczony w kolekcji cyfrowej bazhum.muzhp.pl, gromadzącej zawartość polskich czasopism humanistycznych i społecznych.

Tekst jest udostępniony do wykorzystania w ramach dozwolonego użytku. 


\section{KS. JÓZEF ŁUPINSKI}

Wyższe Seminarium Duchowne w Lomży

\section{DZIEKANI OKRĘGOWI W DIECEZJI WIGIERSKIEJ I DIECEZJI AUGUSTOWSKIEJ CZYLI SEJNEŃSKIEJ}

Treść: Wstęp. 1. Nominacja na dziekana. 2. Wizytacje dekanalne: 2.1. Diecezja wigierska, 2.2. Diecezja augustowska czyli sejneńska, 2.3. Wizytacje dziekańskie a wizytacje biskupie. 3. Czynności urzędowe dziekana: 3.1. Opinia o duchownych, 3.2. Konkursy na beneficja, 3.3. Wprowadzanie proboszcza do parafii, 3.4. Majątek parafialny po śmierci proboszcza, 3.5. Umowy między proboszczami i wikariuszami, 3.6. Rezydencja duchownych, 3.7. Akta stanu cywilnego, 3.8. Przekazywanie wiadomości urzędowych, 3.9. Przenoszenie wiosek do innych parafii, 3.10. Towarzyszenie biskupowi, 3.11. Dozory kościelne, 3.12. Szkoły.

\section{Wstęp}

Dziekan (gr. deka $=$ dziesięć) jest to urząd przełożonego sprawującego określoną władzę w niektórych wspólnotach kościelnych albo godność w niektórych zespołach kolegialnych. Nazwa wywodzi się ze starożytnego zwyczaju prowadzenia dziesięcioosobowej grupy. Jest dziekan okręgowy (vicarius foraneus), dziekan kapitulny, dziekan kardynał, dziekan korpusu dyplomatycznego, dziekan Roty Rzymskiej, dziekan honorowy, dziekan wydziału. W tym opracowaniu chodzi o pierwszego dziekana. Jego urząd wprowadzono po raz pierwszy w państwie Franków celem lepszego zorganizowania i funkcjonowania pracy w diecezjach rozrastających się liczebnie i terytorialnie. W ciągu stuleci zmieniały się uprawnienia i obowiązki dziekanów. Autor zamierza przedstawić takowe dla jednej diecezji, chociaż zapewne były one podobne w innych diecezjach Królestwa Polskiego ${ }^{1}$.

\footnotetext{
${ }^{1}$ T. Pawluk, Dziekan, Encyklopedia Katolicka, t. IV, Lublin 1985, kol. 586-588.
} 
Po trzecim rozbiorze kraju w zaborze pruskim znalazły się niektóre parafie diecezji łuckiej, wileńskiej i żmudzkiej, a stolice biskupie diecezji pozostały w zaborze austriackim i w zaborze rosyjskim. W 1799 r. z tych parafii została utworzona diecezja wigierska. Diecezja augustowska czyli sejneńska została utworzona w $1818 \mathrm{r}$. z terytorium diecezji wigierskiej i z trzech dekanatów diecezji płockiej. Istniała ona do pierwszej wojny światowej.

\section{Nominacja dziekana}

W XIX wieku w diecezji wigierskiej (1799-1818) i augustowskiej czyli sejneńskiej (1818 - I wojna światowa) w dyplomie nominacyjnym na dziekana wyszczególniano następujące jego uprawnienia i obowiązki: wizytować raz w roku wszystkie parafie, zwoływać kongregacje dekanalne, przesyłać w teren ogłoszenia biskupa i konsystorza, towarzyszyć biskupowi w czasie wizytacji generalnej oraz informować go o stanie parafii, powiadamiać biskupa lub konsystorz o wakujących beneficjach wskutek śmierci kapłanów lub $\mathrm{z}$ innego powodu, przedstawiać potrzeby parafii i w ogóle informować biskupa o wszystkim, przedłużać kapłanom jurysdykcję do spowiadania na miesiąc gdy nie zdążą otrzymać od biskupa uprawnień, zarządzać parafią po śmierci jej proboszcza dopóki biskup nie naznaczy innego kapłana, przesyłać do konsystorza testament zmarlych kaplanów i zająć się ich pogrzebem, starać się o zachowanie w całości majątku parafialnego ${ }^{2}$.

Dnia 17 czerwca 1818 r. biskup płocki Adam Michał Prażmowski wydał Instrukcję do duchowieństwa swojej diecezji. W Instrukcji jest mowa o dziekanach, proboszczach, wikariuszach, kongregacjach, rekolekcjach, misjach i konkursach na beneficja. Odnośnie do dziekanów: biskup mianuje dziekanów na przedstawienie konsystorza; konsystorz może zasuspendować dziekana o czym niezwłocznie powiadomi biskupa i przedstawi powody suspensy. Obowiązki dziekana: dziekan sprawuje dozór nie tylko nad beneficjatami swego okręgu, ale i nad kapłanami przebywającym na dworach oraz nad przybyszami, zaś ci ostatni aby mogli odprawiać mszę świętą muszą przedstawić się dziekanowi i otrzymać od niego

${ }^{2}$ Archiwum Diecezjalne w Lomży (skrót: ArEm), Zespół Ogólny (skrót: II), II sygn. 162 k. 26, 36, 75, 114, 117, 145, 199, 216; II sygn. 68 k. 165; II sygn. 71 k. 131; II sygn. 74 k. 45; II sygn. 76 k. 1; II sygn. 187 k. 7; II sygn. 193 k. 6; II sygn. 485 k. 22. 
pozwolenie; co miesiąc dziekan powiadamia konsystorza o zgorszeniach jakie dzieją się w parafii, czy proboszczowie i wikariusze dobrze spełniają swoje obowiązki i o ich obyczajach, o sprawowaniu się obcych księży, których dopuścił lub nie do oltarza; po otrzymaniu wiadomości o śmierci proboszcza dziekan niezwłocznie tam przybędzie, przekaże czasowo zarząd parafii innemu księdzu, dokona spisu dokumentów kościelne, rzeczy gospodarskich, zboże na zasiew, sprawdzi czy fundusz parafii nie uległ pomniejszeniu, a gdyby tak się stało powiadomi o tym komisję wojewódzką i biskupa celem wynagrodzenia braków z masy spadkowej nieboszczyka. Dziekan ma pamiętać o dekrecie królewskim z 6/18 marca 1817 r., którym został zniesiony „,rok łaski”. Spadkobiercy zmarlego proboszcza mogą korzystać z rocznego zbioru tylko za czas życia ich krewnego, reszta zbioru pozostanie na potrzeby parafii. Taki podział dochodu liczy się od 24 czerwca do takiegoż dnia roku następnego. Spadkobiercy otrzymają spadek stosownie do ilości dni pełnienia obowiązków przez zmarłego proboszcza. To samo dotyczy przeliczeń, gdy proboszcz zrezygnowal z pracy w parafii. Przy wprowadzeniu nowego proboszcza do parafii, dziekan sporządzi dokładny spis rzeczy kościelnych i rzeczy gospodarskich, owe spisy opatrzy swoim podpisem i pieczęcią. Każdego roku dziekan zwizytuje kościoly swego dekanatu. Zwróci uwagę na to, czy nie ma skarg na proboszcza co do jego obyczajów i pobierania od wiernych nadmiernych opłat iura stolae, czy w niedziele i święta głosi on nauki katechizmowe, jak proboszcz troszczy się o obyczaje ludzi, w jakim porządku utrzymuje kościół, zakrystię, plebanię, budynki gospodarskie, dokumenty kościelne, czy posiada konieczne mu do pracy książki, czy dobrze prowadzi akta metrykalne, ilu parafian było u spowiedzi wielkanocnej, czy w parafii jest szkoła, kto uczy, ile jest dzieci. Parafię dziekana zwizytuje inny dziekan, ale nie może to być usługa wzajemna, konsystorz ustali porządek wizytacji parafii dziekańskich. Wizytacje mają odbywać się w maju i czerwcu. Dziekan przekazuje proboszczom wszystkie pisma otrzymane z konsystorza i wypełni wszelkie polecenia konsystorza. Dziekan przewodniczy w kongregacjach i rekolekcjach duchowieństwa oraz powiadamia konsystorz o zaniedbujących się w spełnianiu tych praktyk kościelnych. Dziekan powiadamia proboszczów o terminach misji w ich parafiach. Pensja dziekana zależy od ilości parafii w jego okręgu. Dla obwodu lipnowskiego i po 
przyłączeniu do niego dekanatu bobrownickiego 940 zł, dla obwodu płockiego 1140, dla obwodu mławskiego 980, dla obwodu przasnyskiego 580, dla obwodu ostrołęckiego 460, dla obwodu pułtuskiego 700 zł. Dziekani dobrze pełniący swe obowiązki będą mieć pierwszeństwo do prałatur i kanonii kolegiaty pułtuskiej. W innych punktach Instrukcji też wspomniano o dziekanach. W punkcie „proboszczowie”: proboszcz opuszczając parafię na osiem dni ma powiadomić dziekana, na dłużej jak 15 dni zwróci się o pozwolenie do konsystorza. Bez wyrażenia opinii dziekana nie może proboszcz przyjmować sobie do pomocy innego duchownego, a konsystorz nie udzieli zgody na zatrudnienie przez proboszcza innego kapłana. W punkcie „kongregacje”: przewodniczy dziekan, na sześć tygodni przed kongregacją konsystorz przez dziekana przekaże proboszczom tematy kazań do wygłoszenia. Dziekan wyznaczy miejsce odbycia kongregacji. W punkcie „rekolekcje”: termin rekolekcji wyznacza konsystorz w porozumieniu z dziekanem, który przewodniczy rekolekcjom ${ }^{3}$. Instrukcja biskupa Prażmowskiego dotyczyła wprawdzie diecezji płockiej, ale zapewne było podobnie w diecezji augustowskiej czyli sejneńskiej. Właśnie w 1818 r. trzy dekanaty: lomżyński, wąsoski i wiski przeszły z diecezji płockiej do nowoutworzonej diecezji augustowskiej czyli sejneńskiej.

Władze cywilne również wiązały swoje oczekiwania z wizytacją dziekana. Dnia 18 listopada 1820 r. Komisja Rządowa Wyznań Religijnych i Oświecenia Publicznego zwróciła się do biskupów z żądaniem, aby dziekani wizytując corocznie kościoły przekazywali komisarzom obwodowym następujące dane: czy proboszcz utrzymuje w porządku akta stanu cywilnego, czy kościól i plebania potrzebują reperacji, w jakim stanie są zabudowania gospodarskie i co proboszcz uczynił dla polepszenia ich stanu, czy dziekan zastał w całości rzeczy kościelne i gospodarskie, w jakim stanie jest szkoła parafialna, ile dzieci do niej uczęszcza, ile razy na tydzień proboszcz uczy religii w szkole bądź w kościele 4 . Rząd miał też wyraźny wpływ na obsadę stanowisk dziekańskich. Zasadnicze wytyczne do obsady stanowisk kościelnych określiły ukazy carskie z 6/18 marca $1817 \mathrm{r}$. i 14/26 grudnia 1865 r. Odnośnie do funkcji dziekana, w 1817 r. w artykule 14 podano: Biskupi powiadomią Komisję Obrządków

${ }^{3}$ ArŁm, II sygn. 81a k. 1-10.

${ }^{4}$ ArEm, II sygn. 82 k. 19. 
Religijnych i Oświecenia Publicznego o wybranych przez siebie oficjałach, członkach konsystorza i dziekanach. W $1865 \mathrm{r}$. w artykule 8 podano: Dziekana przedstawia władza diecezjalna. Wybór ten ma zatwierdzić komisja rządowa spraw wewnętrznych i duchownych. Nie ogranicza się czasu sprawowania funkcji dziekana. W lipcu następnego roku podzielono duchownych na trzy grupy. Dziekani weszli do grupy drugiej, których uczestników mianowal sam biskup, ale mial wcześniej uzyskać na to formalną zgodę gubernatora miejsca. Przepisy te uległy zmianie w 1884 r. Przed zamianowaniem m.in. dziekanów biskup zwracał się bezpośrednio do warszawskiego generała gubernatora. Również w 1905 r. przypomniano, że dziekana wybierał biskup za zgodą władzy cywilnej, a po zwolnieniu dziekana ze sprawowanej funkcji biskup też powiadamiał odpowiednią władzę cywilną. Ta korzystała ze swoich uprawnień. W 1851 r. zakwestionowała nominację ks. Dąbkowskiego na dziekana. Poinformowała administratora diecezji, że kandydat był zamieszany w rokosz 1831 r., miał procesy sądowe, odmawiał posługi religijnej chorym, w pracy parafialnej najczęściej wyręczał się wikariuszami, wymagał od parafian zawyżonych opłat. Dlatego administrator diecezji ma usunąć ks. Dąbkowskiego od funkcji dziekana, powierzyć te obowiązki godniejszemu kapłanowi i powiadomić komisję rządową o rezultacie poczynań. W 1855 r. komisja rządowa „potrzebując mieć dokładną i kompletną kontrolę wszystkich dziekanów w diecezji” zażądała od każdego z nich przedstawienia szczegółowego życiorysu. Ponadto administrator diecezji miał dołączyć własną opinię o poszczególnych dziekanach, co tenże uczynił i zebrane życiorysy przesłal komisji rządowej. W 1859 r. administrator diecezji powiadomił komisję rządową, że ks. Kolbaczewskiego zwolnił z obowiązków dziekana z racji jego choroby, a powołał ks. Martyszewskiego. Komisja rządowa „akceptując zarządzenie takowe, ma zaszczyt Pana o tym zawiadomic"s.

Niekiedy dziekan miał pomocnika zwano go poddziekanem, zastępcą, wicedziekanem. W 1800 r. biskup wigierski Karpowicz zobowiązał dziekanów, aby sami bądź przez poddziekanów nadesłali mu protokoły wizyt dekanalnych. W $1820 \mathrm{r}$. konsystorz informowal biskupa Czyżewskiego, że dziekan olwitski, ks. Zawadzki odszed1

${ }^{5}$ W. Jemielity, Obsada stanowisk kościelnych w Królestwie Polskim do powstania styczniowego, Prawo Kanoniczne 43 (2000) nr 3-4, s. 352, 384. ArEm, II sygn. 184 k. 109. 
na stanowisko rektora szkoły w Łomży. Ks. Miłkowski nie chce być zastępcą tamtego, a życzy sobie zostać nominowanym aktualnym dziekanem. Ale nie wiadomo, czy ks. Zawadzki zrzeknie się urzędu dziekana. Niech więc biskup sam zadecyduje w tej sprawie, ponieważ nominacje dziekańskie zależą od jego woli. W 1829 r. biskup wyraził zgodę, aby ks. Zienkiewicz zastępując ks. Zybanowicza był poddziekanem. Wkrótce nowym dziekanem został ks. Kuderkiewicz a wicedziekanem ks. Zienkiewicz. Wicedziekan został upoważniony do działania urzędownie w każdej czynności, do której bądź od konsystorz wprost, bądź od dziekana będzie powolany, także do używania tego tytułu w podpisach. W tymże 1829 r. wiekowy ks. Schretter nie dopełniał obowiązków dziekańskich. Biskup sugerował, aby dziekan złożył rezygnację z tego urzędu. W przypadku oporu miał być uznany za niedołężnego urzędownie i wbrew woli usunięty od pelnienia obowiązków dziekańskich. Tymczasem należy powolać na zastępcę dziekana jednego z proboszczów, który przejmie akta dziekańskie i zostanie upoważniony do pobierania pensji. W 1869 r. wakował urząd dziekana dekanatu władysławowskiego. Administrator diecezji upoważnił jednego z proboszczów „do zastępczego pełnienia obowiązków dekanalnych”. W 1876 r. dziekan kolneński wyjeżdzając do wód prosił jednego z proboszczów, aby go zastępował w obowiązku jako dziekana; dziekan powiadomil o tym konsystorza i władzę cywilną. Pobyt u wód przedłużał się, a zastępujący nie wiedział, czy może podpisywać duplikaty akt metrykalnych, prosił o decyzję. Otrzymał odpowiedz z konsystorza, ze obecnie został ustanowiony czasowym zastępcą dziekana, może spełniać wszelkie czynności przypisane do tego urzędu tak prawem kościelnym, jak i krajowym. W 1906 r. dziekani, z uwagi na ich wiek i odległość niektórych kościołów od rezydencji dziekańskiej otrzymali do pomocy wicedziekanów ${ }^{6}$.

Dziekani mieszkali zasadniczo w obrębie swego dekanatu, ale niekiedy i poza nim. W 1819 r. bp Golaszewski zgodził się, aby dziekani mieszkali poza terenem swojego dekanatu. Było to rozwiązanie raczej czasowe, wówczas bowiem następowało nowe rozgraniczenie dekanatów. Natomiast dosyć często dziekani nie przebywali w parafii, od której dekanat otrzymał nazwę. W parafii dzie-

${ }^{6}$ ArEm, II sygn. 56 k. 29; II sygn. 77 k. 26; II sygn. 162 k. 1, 3, 9, 187, 221; II sygn. 553 k. 265. 
kańskiej Wysokie Mazowieckie do 1867 r. nie mieszkał żaden dziekan, parafia ta bowiem była nieliczna i słabo uposażona. Dziekani byli proboszczami innej parafii na terenie tego dekanatu. W $1866 \mathrm{r}$. dokonano nowego podziału administracyjnego w Królestwie Polskim: utworzono dziesięć guberni i osiemdziesiąt pięć powiatów zamiast istniejących dotychczas pięciu guberni i trzydziestu dziewięciu powiatów. Z powiatem miał pokrywać się teren dekanatu, a dziekan powinien był mieszkać w mieście powiatowym, „ażeby zjednoczyć w jednych miejscach tak cywilne, jako też $\mathrm{i}$ duchowne urzędy dla większej dogodności dla władzy". Biskup diecezji sejneńskiej Łubieński szybko zareagował na to rozporządzenie. Na początku tego roku zwolnił pięciu dziekanów i mianował tyluż nowych. Zmiany te przeprowadził bez porozumienia się $\mathrm{z}$ komisją rządową. Ta uznała je za nieważne. Biskup tłumaczyl, że przed ukazem z grudnia 1865 r. nie było potrzeby zwracania się do komisji rządowej. Odpowiedziano mu, że wręcz przeciwnie, ukaz z 1817 r. wyraźnie tego żądal, a w 1865 r. jedynie ponowiono dawne prawo. Biskup miał wyjaśnić, dlacze go zwolnił jednych dziekanów, a mianował innych. Nazwiska tych ostatnich winien przesłać do komisji rządowej po uprzednim porozumieniu się $\mathrm{z}$ gubernatorem augustowskim. Nowych kandydatów na dziekanów przedstawił biskup w drugiej polowie $1867 \mathrm{r}$. Przed wysłaniem ich nazwisk do komisji rządowej zwrócił się do nowych gubernatorów: łomżyńskiego i suwalskiego (te dwie gubernie powstały z guberni augustowskiej), czy nie mają zastrzeżeń pod względem politycznym do przedstawionych kandydatów. Gubernator lomżyński wyrazil sprzeciw wobec ks. P. Krajewskiego, a gubernator suwalski wobec ks. F. Andrzejewskiego. Biskup zrezygnował z drugiego kandydata, ale mocno obstawał przy ks. Krajewskim jako najlepszym na tę funkcję. Gubernator zgodził się na ks. Krajewskiego, ale z zastrzeżeniem, że jeśli toczące się śledztwo udowodni mu winę, biskup będzie musial przenieść go z parafii powiatowej na inną. Biskup sam uznał, że ksiądz przebywający w Kolnie nie nadaje się na dziekana, jednak jest to parafia dziekańska (w mieście powiatowym), dlatego nie może go usunąć ze stanowiska. Władza cywilna zdecydowała, aby proboszcza w Kolnie przenieść na inną parafię. W 1867 r. komisja rządowa uczyniła wyjątek dla trzech dekanatów. W Szczuczynie nie było parafii a jedynie kościól filialny parafii Wąsosz, i tam mieszkal dziekan. W Mariampolu pracowali zakonnicy, a przepisy rządowe 
przewidywały na urząd dziekana kapłana diecezjalnego. W dekanacie wiłkowyskim dziekan nie przebywał w mieście powiatowym, ale miał tam przejść po śmierci podeszłego wiekiem proboszcza parafii Wiłkowyszki ${ }^{7}$. W 1870 r. dziekan łomżyński awansował na stanowisko administratora diecezji i zamieszkał w Sejnach, ale zachował probostwo w Łomży. Na zastępstwo swojego urzędu dziekańskiego zaproponował rządowi dwóch proboszczów z tego dekanatu. Rząd wybrał jednego z ich. Gubernator łomżyński o każdej zmianie dziekana w obrębie guberni powiadamial swoich urzędników, m.in. w 1881 r. pisał do naczelnika powiatu łomżyńskiego, że pewien dziekan przestał pełnić obowiązki, a przejął je inny kapłan. W 1904 r. naczelnik powiatu pytał pewnego dziekana, kto będzie pełnił jego obowiązki, gdy on wyjedzie na leczenie ${ }^{8}$. Nowy dziekan przejmował akta dziekańskie i pieczęć, spisywano protokól. Jeden egzemplarz pozostawał u dawnego dziekana, drugi u nowego dziekana, trzeci protokół przesyłano do konsystorza. W 1850 r. przy zdawaniu dziekaństwa wymieniono siedemnaście pozycjị".

Dziekani z racji pełnionej funkcji otrzymywali wynagrodzenie. W 1821 dziekan łomżyński 390 zł, tykociński, wąsoski, wiski i wysokomazowiecki po $300 \mathrm{zl}$; według ilości kościolów w dekanacie. Sumy te mały być wypłacane w ratach na ręce biskupa bądź za własnoręcznym podpisem dziekana. Pieniądze pochodzily $z$ funduszów zniesionych przez rząd instytutów kościelnych. W 1826 r. komisja rządowa określiła pensje dziekanów na 30 zł od każdego kościoła. Na tę decyzje w 1855 r. powoływał się dziekan łomżyński; zapewne to postanowienie rządowe obowiązywało do powstania styczniowego. W 1868 r. rząd gubernialny augustowski polecił wypłacać dziekanom „podług dawniejszej zasady”, to jest licząc po 4 ruble 50 kopiejek za każdy kościól parafialny, w następnych latach po 150 rubli rocznie ${ }^{10}$.

Księża niechętnie przyjmowali urząd dziekana, zwłaszcza w okresach przesileń politycznych. W 1832 r. bp Manugiewicz pisał,

\footnotetext{
${ }^{7}$ W. Jemielity. Diecezja augustowska czyli sejneńska w latach 1818-1872, Lublin 1972 , s. 69.

${ }^{8}$ W. Jemielity, Mianowanie i przenoszenie księzy w Królestwie Polskim po powstaniu styczniowym, Roczniki Teologiczno-Kanoniczne, tom XXXIV, 1987, zeszyt 4, s. $40,49$.

${ }^{9}$ ArEm, II sygn. 162 k. 3; II sygn. 182 k. 47.

${ }^{10}$ ArŁm, II sygn. 29 k. 148; II sygn. 54 k. 25; II sygn. 162 k. 139; II sygn. 182 k. 59; sygn. II 274 bk.
} 
że na beneficjum często podaje się dziesięciu kandydatów, a na dziekana daje się z trudem wyszukać jednego. Jest to znak, że więcej kapłanów ma ochotę zbierać korzyści niż być pożytecznymi. Konsystorz tłumaczył biskupowi, ze teraz wszyscy lękają się tego urzędu. W trzy lata potem ks. Butrymowicz prosił o zwolnienie z funkcji dziekana. W uzasadnieniu prośby podał, że doświadczył niemało cierpień i przykrości, szczupła pensja dziekańska zaledwie wystarcza na materiały kancelaryjne, odpowiedzialność wielka, ciężar i kłopot znaczny, nagrody żadnej ${ }^{11}$. Niektórzy z dziekanów w prośbie o zwolnienie $z$ urzędu podali, że podczas pełnienia obowiązków dziekańskich doznali wielu przykrości. W 1847 r. dziekan Makowski uznał za rzecz niestosowną i ubliżającą calej kapitule katedralnej, której był członkiem, aby miał się szargać po stajniach i oborach pilnując formalności wskazanych przepisami, gdy może to wykonywać zwykły kapłan ${ }^{12}$.

\section{Wizytacje dekanalne}

\subsection{Diecezja wigierska}

Rok przed formalnym powstaniem diecezji wigierskiej, w sierpniu 1798 r. administrator wspomnianych trzech części diecezji, ks. Gołaszewski pisał, że od dawna istnieją wizytacje dekanalne i przyniosły one wiele pożytku. W ostatnich latach zaistniały pewne niestosowności, które on chce naprawić. Zobowiązuje przeto dziekanów, aby w październiku i do połowy listopada tego roku przeprowadzili wizytacje parafii, biorąc pod uwag następujące zagadnienia: dochody pochodzące z iura stolae, czy proboszcz prowadzi księgi metrykalne zgodnie z przepisami rządowymi, jak zostały wypełnione przepisy zawarte w dekrecie reformacyjnym ostatniej wizytacji, czy parafianie wszystkich kościołów są dostatecznie pouczani słowem bożym, czy mają dostęp do sakramentów, czy nie zanoszą pretensji w związku z opłatami iura stolae, czy rzeczy kościelne i domowe są w należytym porządku, czy nie ma skandali, obniżenia obyczajów, kłótni, waśni rodzinnych i domowych, jak sprawują się administratorzy $\mathrm{w}$ parafiach pozbawionych stałych proboszczów i na podstawie jakich ukladów gospodarczych oni tam pracują, jakie

\footnotetext{
${ }^{11}$ W. Jemielity, Obsada stanowisk kościelnych, s. 384.

${ }^{12}$ W. Jemielity, Diecezja augustowska czyli sejneńska, s. 66.
} 
książki święte i teologiczne posiadają duchowni. Dziekani niech sprawdzają i inne sprawy stosownie do swojej roztropności i doświadczenia ${ }^{13}$. Dnia 31 sierpnia 1805 r. tenże Golaszewski już jako biskup wigierski mianowal ks. Ignacego Rakowskiego wizytatorem dekanatu białostockiego i dał mu wskazówki względem przeprowadzenia wizytacji. Ma ją rozpocząć od parafii w Białymstoku. Weźmie spis wizytacji z roku poprzedniego i porówna, czy wszystko jest zgodne ze stanem obecnym. Niech zbada: czy proboszcz prowadzi księgi metrykalne zgodnie z przepisami rządowymi, jaki jest stan kościola, budynków plebańskich, szat i rzeczy kościelnych, jak duchowni rozdzielają między siebie dochody z iura stolae, czy wikariusze i pracownicy otrzymują stosowne wynagrodzenie, jakie są obyczaje poszczególnych duchownych ${ }^{14}$.

W 1802 r. proboszcz parafii Domanowo (dawna diecezja łucka) w związku z wizytacją dekanalną miał odpowiedzieć na pięćdziesiąt sześć pytań. Pytania przesłał mu dziekan, a ten otrzymał je z kancelarii biskupiej. Mianowicie: nazwa miejscowości, od kiedy jest parafia, kościół drewniany czy murowany; patron parafii; sąsiednie parafie; wioski; ile jest osób do spowiedzi wielkanocnej, czy wypelniają ten obowiązek; liczba dusz, inne wyznania; obszar parafii wzdłuż i wszerz; bractwa; relikwie; oltarz uprzywilejowany; stan kościoła; plebania i zabudowania kościelne; dzwonnica; cmentarz; kostnica; dom wikariusza; ołtarze; sprzęty kościelne; chrzcielnica; księgi metrykalne; oleje święte; tabernakulum; naczyńko do chorych; wieczna lampka; poddani kościelni; opis gruntów parafialnych; dziesięciny; zapisy na parafię; proboszcz, czy sam głosi kazania; porządek nabożeństw; czy są klasztory; przytułek dla ubogich ${ }^{15}$.

W 1804 r. proboszcz parafii Jabłonka (dawna diecezja łucka) ujął swoją odpowiedź według schematu: opis kościoła, sprzęty kościelne jak ornaty, kapy, sukienki do puszki, antepedia, firanki, chorągwie, alby, humeraly, komże, korporały, puryfikatorze, zasłonki do Najświętszego Sakramentu, obrusy, ręczniki, welony, obrazy, srebro, miedź, mosiądz, cyna, żelazo, portatyle, rzeczy drewniane, oraz książki kościelne, księgi metrykalne, porządek nabożeństw, zabudowania plebańskie, grunta kościele, zapisy na

\footnotetext{
${ }^{13}$ ArEm, II sygn. 1 k. 17.

${ }^{14}$ ArEn, II sygn. I k. 240.

${ }^{15}$ Arm, (Zespół Parafialny (skrót: I), I sygn. 355 k. 19.
} 
parafię $^{16}$. Ale dwa lata wcześniej proboszcz tejże parafii Jabłonka przedstawił bardziej szczegółowo stan swojego kościoła (podobnie jak to będzie podane dla 1822 r.).

W 1804 r. w Godlewie (dawna diecezja wileńska) przy wizytacji dekalanej nie podano pytań, a są ujęte zagadnienia: opis kościoła ogólny i szczegółowy: oltarze, podłoga, drzwi; kolatorzy; inwentarz kościelny: ornaty, kapy, chorągwie, alby, humerały, komże, korporały, obrusy, ręczniki, srebro kościelne, miedź, mosiądz, cyna, żelazo, sprzęty drewniane, książki kościelne i plebanijce, katafalk, obrazy, szafki, kropidło; porządek nabożeństw; liczba parafian; pleban: urodzony, wyświęcony, od kiedy plebanem, odprawił rekolekcje; opisanie budowli znajdujących się na Poświętnem; inwentarz kuchenny; opisanie gruntów; zapisy ${ }^{17}$.

W 1804, 1811, 1815 r. w Pilwiszkach (dawna diecezja wileńska) byly również same odpowiedzi: opis kościola, ołtarze, tabernakulum, chrzcielnica, srebra, aparaty, bielizna, księgi kościelne i metryki, cyna i miedź, Sprzęty kościelne, dzwonnica, cmentarz, plebania, przytułek, folwark ${ }^{18}$. W $1805 \mathrm{r}$. w parafiach dekanatu sapieżyńskiego (dawna diecezja żmudzka) proboszczowie podawali: skrótowe opisy kościoła, plebanii, domu organisty, przytułku, ogrodu, nazwisko proboszcza i wikariusza, ich wiek i kiedy otrzymali święcenia ${ }^{19}$. Można tu odnieść się do sąsiedniej diecezji płockiej, z której w 1818 r. trzy dekanaty wejdą do diecezji augustowskiej czyli sejneńskiej. Oto pytania na wizytację dekanalną w $1778 \mathrm{r}$. (w parafii Myszyniec): Nazwa parafii, województwo, ziemia i powiat. Jacy kaplani mieszkają w parafii nie przywiązani do żadnego kościoła. Patroni kościoła. Czy kościół jest konsekrowany. Bractwa. Odpusty. Nazwisko proboszcza, wiek, data święceń. Jego pomocnicy. Stan budynku kościelnego. Domy i składy. Posiadłość parafialna. Rozległość parafii wzdłuż i wszerz. Wioski. Sąsiednie parafie. Liczba parafian. Inne wyznania, żydzi. Uposażenie parafii, dziesięciny, czynsze. Kollatorzy parafii. Sprzęty kościelne czy są dostateczne. Klasztory na terenie parafii. Szkoly publiczne i prywatne. Kaplice prywatne. Bóżnica. Czy w parafii nie ma jakiegoś bezprawia. Porządek

\footnotetext{
${ }^{16}$ ArEm, I sygn. 355 k. 2.

${ }^{17}$ ArEm, I sygn. 114 k. 33 n.

${ }^{18}$ ArŁm, II sygn. 186.

${ }^{19}$ ArŁm, II sygn. $186 \mathrm{k} .1 \mathrm{n}$.
} 
nabożeństw. Jak są zaspokajanie ludziom sakramenty. Czy nie ma księży wagabundów. Jakie są dekrety wizytacji biskupich. Inwentarz probostwa: zboże, stajnie itd. Sprzęty kościelne srebra: kielichy, monstrancje, puszki, krzyże, koronki na obrazy, aparaty: ornaty, alby, komże itd. Rzeczy w refektarzu. Rzeczy kuchenne. Rzeczy browarne. Sprzęt folwarkowy. Sprzęt karczemny ${ }^{20}$.

W 1814 r. konsystorz pułtuski polecil, aby dziekani podczas kongregacji dekanalnych duchowieństwa zażądali od proboszczów pisemnych odpowiedzi na następujące pytania. Jaka jest pobożność w parafii. Ile jest osób zdolnych do spowiedzi wielkanocnej i jak spełniają ten obowiązek. Ilu jest innych chrześcijan, żydów i tatarów. Ilu libertynów, apostatów, publicznych gorszycieli i tym podobnych. Czy jest przytułek parafialny, dla ilu osób, z czego ci ubodzy utrzymują się. Czy jest szkoła parafialna, w zimie ile dzieci do niej uczęszcza. Jakie są książki do nauki własnej duchownego i ludu. Stan kościoła, co zostało w nim ulepszone. Fundusz parafii. Podać swoje uwagi w związku $z$ administracją lub zapytania do przełożonych kościelnych ${ }^{21}$.

W 1820 r. w parafii Piski (diecezja płocka) są odpowiedzi na pytania: Czy w parafii nie ma skarg na plebana względem jego obyczajów lub pobierania nad przepis iura stolae. Czy są regularnie miewane nauki katechizmowe w niedziele i święta. Jaki wpływ na obyczaje ludu i na jego oświecenie ma przykład plebana. W jakim porządku utrzymuje on kościół i zakrystię. Stan kościoła i plebanii, jeżeli zły, to jakie kroki czynił o reperację. Stan budynków gospodarskich, których reperacja należy do proboszcza. Czy jest pilny w gospodarstwie. Czy nie zaniedbuje funduszu. Czy czyni starania o odzyskanie awulsów. Czy dokumenty kościelne są w porządku. Czy posiada książki istotnie potrzebne: Pismo Święte, sobór trydencki, teologię, kazania, katechizm, i jakich autorów. Czy metryki kościelne i akta cywilne utrzymuje w przyzwoitym porządku. Ilu parafian było u spowiedzi wielkanocnej. Czy jest szkoła parafialna, jaka jest zdolność i moralność nauczyciela, wiek dzieci zdatnych do nauki, ilu chodzi do szkoły. Czy pleban dopełnia zalecenia rządowe. Ile ma drzew owocowych i jakie. Czy dom jest obsadzony topolami lub innymi drzewami, ile sztuk jest na wysadzanie dróg. Czy

\footnotetext{
${ }^{20}$ ArŁm, II sygn. $160 \mathrm{k} .2 \mathrm{n}$.

${ }^{21}$ ArEm, II sygn. 163 k. 104.
} 
jest miejsce na cmentarzu do grzebania dzieci nie ochrzczonych i tych, co nie po katolicku schodzą z tego świata. Jaki jest stały dochód proboszcza. Jakie reperacje obok kościoła i dachów plebańskich on poczynit. W $1824 \mathrm{r}$. w tejże parafii Piski miejscowy proboszcz odpowiadal na te same pytania jak wyżej oraz na dodatkowe pytanie odnośnie sprzętów kościelnych ${ }^{22}$.

Około 1818 r. w parafii Niedżwiadna (wówczas diecezja płocka, następnie diecezja augustowska czyli sejneńska): „Artykuły według których dziekani wizyty kościołów sobie podległych corocznie odprawiać mają". 1. Nazwa miasta czy wsi w miejscu gdzie jest kościól, ten zaś w jakim stanie. 2. Cmentarz przy kościele czy dobrze oparkaniony i zamykany. 3. Czy jest osobny cmentarz za miastem lub wsią, i jak jest utrzymywany. 4. Czy są, według nowego rozporządzenia, prowizorowie utrzymujący wspólnie $\mathrm{z}$ rządca kościoła kasę parafialną. Jak są jej dochody i na co wydawane. 5. Nazwisko proboszcza i innych księży, stopień, wiek, lata w kapłaństwie. 6. Opinia o każdym z księży: czy nie mają nałogów, czy spełniają swoje obowiązki, czy nie pozostają z kim w widocznej nienawiści. 7. Czy ktoś nie umarł bez sakramentów z powodu opieszałości duchownych. 8. Czy pleban lub wikariusz nie czyni ludziom przykrości z powodu iura stolae, czy nie pobiera oplaty za kartki do spowiedzi wielkanocnej, czy z powodu spraw prywatnych nie utrudnia komu spowiedzi wielkanocnej. 9. Czy nie zadłuża się z przyszłą przewidzianą szkodą kościoła. 10. Czy regularnie odprawia nabożeństwa parafialne, a sumę zaczyna nie wcześniej jak o godzinie dziesiątej i kończy nie później jak o godzinie dwunastej. 11. Czy nie opuszcza nauk i kazań, z jakich autorów korzysta. 12. Czy nie sprawuje obrządków kościelnych w sukni świeckiej a tym bardziej kolorowej. 13. Czy oleje święte sprowadza w odpowiednim czasie i trzyma je pod zamknięciem. Jak często dopełnia renowacji Najświętszego Sakramentu. 14. Czy w księdze fundacji zapisuje wykonanie podjętych zobowiązań. 15. Jeśli jest urzędnikiem cywilnym, to czy dobrze prowadzi akta urodzeń, małżeństw i zejścia oraz czy nie pobiera opłat ponad przepisane prawem. 16. Czy dokładnie prowadzi księgi kościelne chrztów, ślubów i pogrzebów. 17. Czy utrzymuje w przyzwoitym porządku kościól. 18. Jakich reperacji

${ }^{22}$ ArEm, II sygn. 160 k. 53, 331; I sygn. 370 k. 303. 
dokonał w kościele. 19. Czy w kościele jest dosyć potrzebnych aparatów. 20. Co za staraniem plebana przybyło do kościoła po ostatniej wizycie. 21. Pleban sam prowadzi gospodarstwo gruntowe lub oddaje w dzierżawę. 22. Czy wypłaca czeladzi zasługi bez ich pokrzywdzenia. 23. Stan budowli należących do plebana. 24. Czy nie nastąpil ubytek rzeczy w gospodarstwie. 25. Stan zasiewów. 26. Czy w parafii nie ma zabobonów lub jawnych pogorszeń. 27. Czy jest szkoła elementarna, ilu ma uczniów. 28. Czy jest odrębna szkoła dla dziewcząt. 29. Czy proboszcz lub wikariusz często wizytuje szkołę elementarną lub czy przynajmniej uczą dzieci religii w niedziele i święta. 30. Czy proboszcz swoim wpływem dopomaga do utrzymania szkoły elementarnej ${ }^{23}$.

\subsection{Diecezja augustowska czyli sejneńska}

W 1822 r. bp Czyżewski przesłał dziekanom pytania do przeprowadzenia wizytacji dekanalnej. Z wielu parafii zachowały się odpowiedzi, np. z Jabłonki i Wysokiego Mazowieckiego (dawna diecezja łucka), Pilwiszek (dawna diecezja wileńska), Białaszewa i Niedźwiadnej (dawna diecezja płocka). Oto pytania: 1. Kościół parafialny podług swego położenia i stanu. Nazwa kościoła, powiat i dekanat. Kościół murowany czy drewniany, jakiej formy, kiedy i przez kogo postawiony, konsekrowany bądź błogosławiony. Które parafie są przyległe i w jakiej odległości. Jak daleko są od kościoła większe miasta i spławne rzeki. Które i jakie strumyki są na terenie parafii i do jakiej rzeki wpadają. Ile i jakie wioski należą do parafii, czyją są własnością. Czy w innym powiecie nie ma wsi i gruntów danej parafii. Ile osób przystępuje do komunii i czy wszyscy spełnili obowiązek. Ogólna liczba parafian razem z dziećmi, ilu jest innych chrześcijan i żydów. Rozległość parafii wzdłuż i wszerz. 2. O ołtarzach, prebendach i innych beneficjach. Ile jest ołtarzy, czy są konsekrowane a portatyle $z$ relikwiami czy są opatrzone dobrymi pieczęciami. Czy ołtarze są przykryte przynajmniej trzema obrusami i ozdobione obrazami przyzwoicie namalowanymi. Czy które z obrazów są słynące łaskami. Czy jest w parafii jakaś kaplica lub prebenda, przez kogo uposażona, kto jest kollatorem. Sprzęty kościelne: ornaty, kapy, książki kościelne, chorągwie, alby, komże, korpo-

\footnotetext{
${ }^{23}$ ArEm, I sygn. 327 k. 2.
} 
rały, srebro kościelne, cyna, żelazo, sprzęty drewniane, szkło. 3. O chrzcielnicy i chrzcie. Czy chrzcielnica jest odpowiednio zaopatrzona i zamknięta. Czy chrzest dzieci odbywa się w trzy dni po ich urodzeniu. Czy są baby zdatne do przyjmowania dzieci, jakie ich obyczaje, czy potrafią udzielać chrztu w niebezpieczeństwie życia noworodków. 4. O Przenajświętszym Sakramencie i ostatnim namaszczeniu. Czy jest odpowiednio przechowywany. Ile razy na miesiąc są zmieniane komunikanty. Dni wystawienia publicznego i noszenia w procesji. Czy puszka jest ozdobiona jedwabną sukienką. Czy puszka jest srebrna lub z innego metalu, wewnątrz wyzlocona, konsekrowana. Czy przed Sanctissimum zawsze pali się lampa, czy tylko czasem i czyim kosztem. 5. O bractwach i relikwiach. Czy jest bractwo, jakie, przez kogo założone. Czy ma przepisane jakie postanowienia i czy je zachowuje. Skąd jest przychód bractwa i kto nim zawiaduje. Czy relikwie są autentyczne i dobrze opieczętowane. Czy do któregoś oltarza są przypisane odpusty uprzywilejowane. 6. O pobudowaniu kościoła i o stanie zabudowań. Stan kościoła i jego opis. Jaka dzwonnica. Ile jest dzwonów. Czy jest oddzielny cmentarz. Czy jest wydzielone miejsce dla dzieci zmarłych bez chrztu. Czy jest kostnica. W jakim stanie jest plebania i inne zabudowania należace do proboszcza. 7 . O rzeczach ekonomicznych beneficjum, uposażeniu, prawach i dokumentach kościoła. Inwentarz należący do ekonomii w jakim jest stanie. Czy obecny proboszcz otrzymał od poprzednika inwentarz i czy nie umniejszył tych rzeczy. Czy są folwarki i poddani. Opis pól, ogrodów, łąk, gruntów, lasów, stawów. Czy jest wolny wyszynk. Jakie są dziesięciny: snopowe, pieniężne, w ziarnie. Czy są legaty na rzecz kościoła. Kto ma klucz od skarbony kościelnej, na co są obracane pieniądze. Przychody i wydatki roczne proboszcza. Czy jest księga do zapisywania rozporządzeń biskupich i rządowych. 8. O plebanie i innych kaplanach znajdujących się w parafii. Pleban: imię, nazwisko, wiek, jakie posiada godności, czy zawsze pozostaje przy parafii. Data święceń i objęcia beneficjum. Czy pochodzi z tej diecezji. Czy posiada jedno beneficjum lub więcej. Czy sam lub inny kapłan głosi w niedziele i święta kazania lub nauki katechizmowe. Z jakich książek korzysta do kazań. Podać dane o innych kaplanach. Czy kapłani gorliwie udzielają sakramentów, szczególnie chorym. Porządek nabożeństw w parafii. 9. O szkole parafialnej. Czy są jacy nauczyciele lub inne osoby, by uczyli chłopców. Czy pleban odwiedza szkołę. 10. O za- 
konnikach i zakonnicach. Czy na terenie parafii są jakieś zgromadzenia zakonne, ile osób, jak zachowują klauzurę. 11. O szpitalach. Czy jest szpital (przytułek dla ubogich), ile osób, kto ich utrzymuje. 12. O kaplicach. Czy na terenie parafii znajdują się kaplice i świątynie innych wyznañ ${ }^{24}$. Te pytania były związane $z$ wizytacją biskupią poszczególnych parafii.

W latach 1824-1829 byly następujące pytania dotyczące „rocznej wizyty dziekańskiej”. Miejsce kościoła. Czy proboszcz utrzymuje w porządku akta cywilne. Czy kościół i plebania potrzebują reperacji. W jakim stanie proboszcz utrzymuje zabudowania gospodarskie i co zrobił dla polepszenia ich stanu. Czy dziekan zastał w calości fundusz miejscowy. W jakim stanie jest szkoła parafialna, ile dzieci do niej uczęszcza, jak dla nich dawana jest nauka religii przez miejscowego duchownego, to jest w kościele czy w szkole. Rewizja kasy cmentarzowej: dzień, miesiąc, rok, przychód w kasie złotych i groszy, rozchód w kasie złotych i groszy, pozostaje w kasie złotych i groszy. Stan cmentarza: przy kościele, w polu. Adnotacje ${ }^{25}$.

W 1837 r. nowo mianowany bp Straszyński polecił dziekanom odpowiedzieć na następujące pytania: Nazwa kościoła, czy jest na wsi lub w mieście. Jakiej kollacji: prywatnej, rządowej czy przemiennej, podać nazwiska kollatorów. W jakim obwodzie i powiecie jest położony kościól. Rozległość parafii, liczba ludności. Ile jest wsi w parafii, odległość do kościoła, do kogo należą, podać nazwiska właścicieli. Źródło utrzymania parafii, przychód roczny. Nazwiska kapłanów w parafii i sposób ich prowadzenia się. Porządek nabożeństw niedzielnych i świątecznych, w jakim języku głosi się nauki. Jakie są bractwa. Czy istnieje szkółka parafialna, ile dzieci do niej uczęszcza, kto uczy. Stan kościoła i zabudowań plebańskich. Czy są kaplice publiczne w domach wyższych osób. Najbliższa stacja pocztowa ${ }^{26}$. Bp Straszyński chciał bliżej poznać diecezję, pytania były podobne jak przy rocznych wizytacjach dziekańskich.

W 1874 r. dziekani otrzymali z konsystorza pytania na wizytację dziekańską pytania. Następnie mieli zebrać z parafii odpowiedzi

${ }^{24}$ ArŁm, I sygn. 26 (Białaszewo) bez karty; I sygn. 144 k. 66; I sygn. 327 k. 8; I sygn. 368 bk; I sygn. 623 k. 2 n.

${ }^{25}$ ArEm, II sygn. 155 k. 2; II sygn. 166 k. 139; II sygn. 167 k. 104; II sygn. 168 k. 226; II sygn. 169 k. 83.

${ }_{26}$ ArEm, II sygn. 156 k. 1 n; II sygn. 157 k. 1. 
przekazać je do Sejn. Były dwadzieścia trzy pytania. 1. W jakiej miejscowości znajduje się kościól, kiedy zbudowany, z jakiego materiału, w jakim jest stanie. 2. Cmentarz przykościelny, jego stan, czy jest zamykany. 3. Czy jest cmentarz grzebalny odrębny, w jakim stanie, czym ogrodzony. 4. Pod czyim dozorem pozostaje kasa cmentarna. 5. Imię i nazwisko księży w parafii, ich wiek, od jak dawna są w obecnym miejscu. 6. Jakie jest ich postępowanie, czy regularnie spełniają swoje obowiązki. 7. Czy kto przez opieszałość duchownych nie umarł bez przyjęcia sakramentów. 8. Czy proboszcz nie pobiera nadmiernych oplat, czy kartki do spowiedzi wielkanocnej są nieodpłatne, czy z powodów prywatnych albo z racji swojej opieszałości nie utrudnia komu spowiedzi wielkanocnej. 9. Czy regularnie odprawia nabożeństwa niedzielne i świąteczne, o jakiej porze. 10. Czy w niedziele i święta głosi nauki, o jakiej porze. 11. Czy nie sprawuje obrzędów kościelnych w sukni świeckiej. 12. Czy posiada oleje święte, gdzie je przechowuje, jak często odnawia je w naczyńku. 13. Czy dobrze utrzymuje akta urzędnika stanu cywilnego. 14. Czy troszczy się o czystość w świątyni. 15. Czy przed Najświętszym Sakramentem lampka pali się dniem i nocą. 16. Jakie prace wykonał przy remoncie kościoła. 17. Dokonać spisu przedmiotów kościelnych. 18. Czy coś przybyło w kościele po ostatniej wizytacji biskupiej. 19. Wymienić grunty kościelne, proboszcz uprawia sam lub oddał w dzierżawę. 20. Czy ksiądz wypłaca regularnie swojej służbie. 21. W jakim stanie są budowle należące do probostwa. 22. Czy nie ulegl zmianie inwentarz gospodarski od czasu objęcia probostwa. 23. Dokonać opisu kościola i jego sprzętów ${ }^{27}$.

W 1883 r. konsystorz przesłal dziekanom „Sposób przeprowadzania wizytacji dziekańskiej”. Kopia. Do Nr 854. (Wpisane do księgi rozporządzeń po 7 sierpnia 1883 r.). Mianowicie: dzień i rok wizytacji kościoła NN. Wizytacja Najświętszego Sakramentu: jak jest wykonana i ozdobione tabernakulum, gdzie ono znajduje się, czy jest korporal, ile jest puszek i jakie, czy są i jakie naczyńka, w których zanosi się Najświętszy Sakrament chorym, czy renowacja Najświętszego Sakramentu odbywa się co osiem dni. Wizytacja relikwii: czy są relikwie i jakich świętych, gdzie i w jaki sposób są przechowywane. Chrzcielnica: czy jest wykonana prawidłowo

${ }^{27}$ ArEm, II sygn.. 72 k. 20. 
i ozdobiona, jak często w ciągu rok są zmieniane oleje święte do chrztu. Inne oleje święte gdzie, jak i czy godnie są przechowywane i czy nie razem z Najświętszym Sakramentem. Ołtarze: ile jest oftarzy, czy są wykonane $z$ trwalego materiału, czy w oltarzach są portatyle, czy na ołtarzu znajdują się przynajmniej trzy obrusy i jakie, czy obrazy w ołtarzach są odpowiednie. Czy są kaplice i ile. Rzeczy kościelne: ile jest i jakich ornatów, kap, alb, kielichów, paten, krzyży, monstrancji, korporałów, palek na kielichy, puryfikatorzy, trybularz, figura Chrystusa Zmartwychwstałego, mszal, rytuał, ewangeliczka, śpiewnik kościelny. Kościól: czy konsekrowany, czy wymaga reperacji. Kto jest patronem kościoła. Czy jest jakieś bractwo i kiedy zostało ustanowione. Czy są nadane odpusty i od kogo. Cmentarz: czy poświęcony, czy ogrodzony. Proboszcz: czy przebywa w parafii, czy ma odpowiednich współpracowników, czy oni rezydują w parafii, czy są w wystarczającej liczbie do potrzeb duszpasterskich, czy mają zapewnione utrzymanie. Jak są prowadzone księgi metrykalne chrztów, małżeństw i zmarłych. Ile jest wsi w parafii, ilu wiernych. Czy jest księga zawierająca spis imion i nazwisk parafian. Ilu parafian przystąpiło do spowiedzi wielkanocnej a ilu nie przystąpiło. Czy ktoś zmarł bez sakramentów. Czy są w parafii publiczni grzesznicy lub heretycy. Stan budynków kościelnych. Jacy są domownicy proboszcza. Zycie i zachowanie się kapłanów: wzajemne relacje proboszcza i jego współpracowników, kiedy każdy z nich odbył spowiedź, jakie książki posiadają, zbadać zachowanie się każdego kaplana, czy nie nadużywa alkoholu, czy nie gra w karty. Skarbonki kościelne: czy są takowe, ile ofiar złożono, na co zostały one przeznaczone ${ }^{28}$.

W 1885 r. „Protokół wizyty dziekańskiej parafii NN” zawierał następujące pytania. Najświętszy Sakrament: jak jest zbudowane i przyozdobione tabernakulum, gdzie umieszczone, czy pod Najświętszym Sakramentem jest położony korporal, ile jest puszek i jakie, czy są oddzielne naczynka na wiatyk do chorych, Czy co osiem dni są odnawiane postacie Najświętszego Sakramentu. Relikwie świętych: czy znajdują się i jakich świętych, gdzie są przechowywane i z jakim poszanowaniem. Chrzcielnica: czy dobrze wykonana i ozdobiona, gdzie znajduje się, czy woda do chrztu zawiera

\footnotetext{
${ }^{28} \mathrm{ArEm}$, II sygn. $71 \mathrm{k} .16$.
} 
w sobie oleje święte, czy woda jest zawsze czysta, ile razy na rok bywa zmieniana. Oleje święte: czy parafia posiada je i skąd, gdzie są przechowywane, czy oddzielnie od Najświętszego Sakramentu. Ołtarze: ile jest ołtarzy, czy są konsekrowane, czy nie są zrujnowane a portatyle cale, czy we wszystkich oltarzach są portatyle i czy są konsekrowane, czy na ołtarzach są po trzy obrusy i z jakiego materiału, obrusy w ołtarzach czy są piękne i ozdobne. Kaplice: czy są i ile ich jest. Apparata kościelne: ile jest i jakich ornatów, kap, alb, komż, z jakiego materiału i gdzie są przechowywane, ile jest kielichów, paten, krzyży, monstrancji i jakich, ile jest lichtarzy i z jakiego materiału, ile jest korporałów, palek, puryfikatorzy, z jakiego materiału i czy są czyste. Wino i hostie do mszy świętej. Czy co roku stawia się nowy paschał, czy jest odpowiednia figura Zmartwychwstania Pańskiego. Książki kościele: ile jest mszałów i jakie, rytuały, kancjonały, ewangeliczki. Kościól: czy konsekrowany, czy sam potrzebuje reperacji, czy dach potrzebuje reperacji. Kollator kościoła jest jeden czy więcej i jacy. Czy jest bractwo i przez kogo zaprowadzone. Czy kościól posiada jakieś odpusty i przez kogo nadane. Cmentarz czy jest poświęcony i oparkaniony. Proboszcz i wikariusz: czy proboszcz zawsze mieszka przy kościele, czy ma on odpowiednich pomocników, którzy rezydują przy kościele i mają odpowiednie utrzymanie. Czy są księgi urodzonych, zaślubionych i zmarłych. Ile wsi i ludności należy do parafii. Czy jest prowadzona księga $\mathrm{z}$ imionami i nazwiskami parafian. Czy wszyscy są katolikami. Czy wszyscy odbywają spowiedź wielkanocną, jeżeli nie, to z jakich przyczyn. Czy ktoś umarł bez sakramentów i z jakich powodów. Czy znajdują się w parafii publiczni grzesznicy lub heretycy. Stan ekonomiczny zabudowań plebańskich. Służba w domu plebańskim: należy uważać jak liczna jest służba, czy prowadzi się moralnie, skromnie, pobożnie i wstrzemięźliwie. Zycie i prowadzenie się kapłanów: kiedy każdy z nich spowiadał się, przed jakim kapłanem, jakie książki każdy posiada, dowiedzieć się o życiu i prowadzeniu się każdego z nich, czy nie oddaje się pijaństwu, niewstrzemięźliwości, grze w karty, czy nie uczęszcza do miejsc podejrzanych lub nie dopuszcza się lichwy, jak często odprawia mszę świętą, czy zachowuje rubryki przepisane w mszale, jak układa się życie między proboszczem i wikariuszem. Skarbona kościelna: czy jest takowa i pod czyim nadzorem zostaje, ile wpływa ofiar i na co są wydawane. Czy wiernie są zachowywane 
wszystkie przepisy dekretu reformacyjnego ostatniej wizyty biskupa w parafii ${ }^{29}$.

\subsection{Wizytacje dziekańskie a wizytacje biskupie}

Powstaje pytanie, czym różnily się formularze wizytacji dziekańskich od formularzy wizytacji biskupich. W maju $1821 \mathrm{r}$. bp Czyżewski zapowiadając swoją wizytację diecezji polecił „wcześniej opisać stan i fabrykę kościoła, fundusze, zapisy, przywileje, prawa, stan gospodarczy, inwentarz sprzętów domowych i kościelnych, zgoła to wszystko, co się ściąga do chwały Boskiej, sprawowania sakramentów, dobra kościoła i samych kapłanów”. Podobnych spraw dotyczyły formularze wizytacji dekanalnych, $\mathrm{z}$ jednym ważnych wyjątkiem - sprawowania sakramentów. W sierpniu 1821 r. biskup wymienił pytania: nazwa miejsca kościoła parafialnego, filialnego lub zakonnego, imię, nazwisko, wiek kapłana, od jakiego czasu jest w parafii, data erekcji parafii czy zachowała się w aktach parafialnych, zobowiązania funduszowe, stan świątyni, rzeczy w kościele i zakrystii, zabudowania gospodarcze, inwentarz gospodarski, nazwa wsi i odległość do kościoła, ilu jest katolików, innych chrześcijan i żydów, cmentarz grzebalny, kasa cmentarna, księgi metrykalne, kto jest urzędnikiem stanu cywilnego, szkoła, osoby gorszące w parafii, dowody funduszów. W marcu $1822 \mathrm{r}$. biskup rozszerzył listę pytań, a raczej sprecyzowal poprzednie: położenie parafii 12 pytań, ołtarze i wystrój kościoła 5, chrzest 7, Najświętszy Sakrament i ostatnie namaszczenie 5 , bractwa i relikwie 5, stan świątyni i plebanii 7 , uposażenie beneficjum 13, proboszcz i inni duchowni 10 , szkoła parafialna 2, klasztory 4, przytułek parafialny 3, kaplice 5 pytań. W 1837 r. bp Pawel Straszyński podał trzysta dwadzieścia pięć pytań ułożonych w czternastu niejako rozdziałach: położenie i stan parafii 22 , stan materialny świątyni 13 , sprzęty kościelne 10 , oltarze i obrazy 14, relikwie i odpusty 14, prebendy i beneficja odrębne 6 , bractwa 13, kaplice publiczne i prywatne 19, drukarnia, szkoła parafialna i przytułek 23 , sakramenty: chrzest 12 , bierzmowanie 4 , eucharystia 12 , pokuta 11 , ostatnie namaszczenie 6 , ma1żeństwo 8, proboszcz, wikariusz, inni duchowni, pracownicy kościelni 76, zakonnicy i zakonnice 30, parafianie 9, gospodarstwo

${ }^{29}$ ArŁm, II sygn. 158 k. 40. 
proboszczowie, zapisy, dokumenty 23 pytań. W 1873 r. bp Wierzbowski powtórzył pytania wizytacyjne bpa Straszyńskiego, podobnie w 1898 r. bp Baranowski. W 1911 r. bp Karaś polecił uwzględnić w odpowiedziach: kościól 15 pytań, ołtarz wielki 21, ołtarze boczne 9 , chrzcielnica 4 , szafy w zakrystii 2 , ambona 2 , konfesjonały 3 , naczynie do wody święconej 1 , zakrystia 12 , naczynia święte 16 , ornaty 19 , obrusy 8 , inne przedmioty liturgiczne 5 , księgi 3 , biblioteka 4, dzwonnica 6, cmentarz 14, dom przedpogrzebowy 2, kaplice publiczne 11, kaplice prywatne 6, porządek nabożeństw 36, zapisy mszalne 2 , bractwa 13 , przytułek parafialny 6 , szkoła 5 , działalność społeczna 6, zabudowania parafialne 8, uposażenie kościoła 2, uposażenie proboszcza 12, uposażenie wikariusza 5, uposażenie pracowników kościelnych 3, parafianie 4, archiwum kościelne 21, proboszcz 26, wikariusz 20, inni duchowni 4, pracownicy świeccy 3 , obyczaje parafian 24, uwagi 1; razem 367 pytań $^{30}$. Formularze wizytacji dziekańskich dotyczyly więc raczej stanu budowli kościelnych i uposażenia duchownych, formularze wizytacji biskupich zawierały częśsiowo to co tamte, ale ponadto szczególowo odnosiły się do życia sakramentalnego i duchowego parafii. W okresie po powstaniu styczniowym w obu rodzajach wizytacji: dziekańskich i biskupich są prawie pomijane gospodarstwa proboszczowskie i zapisy na rzecz parafii, gdyż zostaly one przejęte na skarb państwa.

\section{Czynności urzędowe dziekana}

\subsection{Opinie o duchownych}

W 1788 r. oficjał konsystorza lomżyńskiego przypominal dziekanom, że są stróżami wszystkich ustaw diecezjalnych. Dlatego mają powiadamiać wyższą władzę o złym postępowaniu duchownych. Jeśli więc będą pobłażać, milczeć i nie powiadamiać przełożonych o winie innych, ściągną na siebie połowę kary tamtych. W 1813 r. biskup wigierski Jan Gołaszewski wzywał dziekanów, aby dołożyli wszelkich starań „na wyrwanie tego kąkolu spomiędzy pszenicy, na wytępienie złych przykładów i zgorszeń spomiędzy kapłanów". W 1814 r., konsystorz polecał dziekanom, aby podczas kongregacji dekanalnej brali pojedynczo księży na stronę, sekretnie i po brater-

${ }^{30} \mathrm{~W}$. Jemielity, Wizytacje biskupie w diecezji augustowskiej czyli sejneńskiej, Studia Teologiczne 17 (1999) s. 239. 
sku upominali winnych. Niech dziekan zapyta każdego proboszcza o jego wikariusza i wzajemnie, gdyby miał jakie podejrzenie co do ich postępowania. W 1817 r. nowo mianowany biskup płocki Prażmowski polecił dziekanom przeprowadzić wizytację parafii i dać mu sprawozdanie m.in. o stanie moralnym kaplanów. W 1820 r. biskup płocki polecił, aby na przyjazd dziekana wezwać kollatora i parafian. Mieli oni wypowiedzieć się o obyczajach duchowienstwa, była też okazja do usunięcia ewentualnych zatargów w sprawach materialnych. W 1822 r. wśród pytań przesłanych na wizytację dekanalną byly następujące: „Konduita każde go z księży. Czy który nie podpada złym nałogom. Czy spełnia swe obowiązki. Czy z kim w widocznej nienawiści nie zostaje". Dziekan mógł nie zaznaczać tej odpowiedzi na arkuszu wizytacyjnym, a w formie zapieczętowanego listu przesłać do konsystorza. W 1826 r. nowo mianowany biskup sejneński Manugiewicz zwrócił się do dziekanów, aby o każdym z kaplanów dali sumienną i roztropną opinię: czy żyje przykładnie i po kapłańsku, czy nie daje z siebie jakiego zgorszenia i nie ma w parafii złej opinii o sobie, czy spełnia obowiązki parafialne i jak jest użytecznym w tym miejscu, w którym zostaje. Słowem należy opisać stan moralny i postępowanie każdego kapłana z odniesieniem do jego powołania, obowiązku lub urzędu. Biskup bowiem chce usunąć nadużycia u jednych a nagrodzić innych. W miesiąc potem biskup zażądał takich sprawozdań co kwartal, ale sumiennych i sprawiedliwych, i to nawet pod karą utraty urzędu dziekańskiego. W 1829 r. tenże biskup przesłał bardziej szczegółową listę pytań dotyczących obyczajów i pełnienia obowiązków, oddzielnie dla proboszczów i dla wikariuszy. Biskup zaznaczył, by drugie osoby nie wiedziały, jaka opinię wystawił dziekan. Jego samego oceni konsystorz. Oto przykłady opinii dziekańskich. W 1837 r. w dekanacie kalwaryjskim na 21 księży otrzymali ocenę: dbałość w administracji: dobra 18, nienaganna 1, mierna 1, czy w kościolach są regularnie kazania i nauki: regularnie 15 , odbywają się 2, czasami opuszcza 1, czy kto nie umarł bez sakramentów z winy proboszcza: nikt nie umarł, obyczaje: dobre 15, nieszczególne 2, chwalebne 1, nienaganne 1 , płoche 1 , czy był kiedy napominany: nikt, ale jeden ma charakter burzliwy. W 1842 r. w dekanacie kalwaryjskim na 17 kapłanów: obyczaje: dobre 13, nieszcze gólne 2, nienaganne 1, lubi zabałamucić 1, czy był karany: nie był 14, upominany przez dziekana 1, ukarany rekolekcjami 1. W 1844 r. w dekanacie sejneńskim na 
14 kapłanów - pilność w administracji sakramentów: bardzo pilny 5 , dosyć pilny 5 , nie pilny 1 , nie ze wszystkim pilny 1 , był pilny teraz w starości funkcji kapłańskich nie spełnia 1, oziębly w udzielaniu sakramentów 1 , obyczaje: dobre 5 , najlepsze 3 , nienajlepsze 2 , wzorowe 1 , niedobre 1 , nie odpowiada powolaniu kapłańskiemu 1, czy był kiedy napominany: nie był 9, był 5 osób. W 1874 r. wśród pytań przysłanych $z$ konsystorza na wizytację dziekańską były: jaka jest opinia o księżach danej parafii, czy nie mają złych nałogów, czy regularnie spełniają swoje obowiązki, czy nie pozostają z kim w widocznej nienawiści. W 1883 r. bp Wierzbowski zarzucił dziekanom, że nie powiadamiali go o wyjeździe księży poza teren swoje parafii. Tymczasem, pisał, z wiarygodnych źródeł dochodzą wiadomości o ich nieobecności w parafii tygodniami a nawet miesiącami. Dziekani zaciągną winę wobec Boga i wobec biskupa. W 1920 r. bp Jałbrzykowski przypomnial dziekanom ich obowiązki określone w prawie kanonicznym. Przynajmniej raz w roku mają wizytować swój dekanat, by zapobiegać złemu na początku i nie doprowadzać w parafii do zgorszenia i sądów. Mają sprawdzać księgi metrykalne, księgi rachunkowe i księgi stypendialne. Każdy ksiądz zawiadomi dziekana $\mathrm{w}$ wyjeździe $\mathrm{z}$ parafii, by otrzymać $\mathrm{w}$ porę zastępstwo. Zdanie dziekana będzie brane w konsystorzu bardzo poważnie, co też powinno oddziaływać i na postępowanie księży w myśl porządku prawnego. Dziekan ma być nie tylko dla honoru, ale i dla obowiązku. W 1922 r. dziekani mieli przestrzec księży, aby nie brali udziału w grach hazardowych ${ }^{31}$.

\subsection{Konkursy na beneficja}

W okresie do powstania styczniowego od przyszłych proboszczów wymagano złożenia egzaminu. Kandydat na proboszcza miał przedstawić szereg dokumentów, m.in. opinię swojego dziekana. Wymagał tego rząd i biskup. Oto kilka przykładowych.. Dziekan wiski stwierdzil, że ks. Walenty Zaleski pracował gorliwie jako wikariusz i zachowywał się poprawnie. Dziekan sejneński - ks. Onufry Wojtkiewicz był w dekanacie jedenaście lat, okazy-

${ }^{31}$ ArEm, II sygn. 54 k. 121, 192; II sygn. 71 k. 115; II sygn. 72 k. 20; II sygn. 73 k. 172 , 173; II sygn. 81a k. 65; II sygn. 84 k. 5; II sygn. 163 k. 105, 144; II sygn.. 178 k. 47; II sygn. 179 k. 39; II sygn. 181 k. 2, 33; II sygn. 182 k. 1, 4; II sygn. 186A; II sygn. 506 k. 24; I sygn. 327 k. 2. 
wał gorliwość pasterską, jego osobiste życie stanowiło przykład dla otoczenia. Dziekan wysocki - ks. Jan Stypułkowski był sześć lat wikariuszem, chętnie glosił kazania i udzielał sakramentów, budował parafian pobożnością. Dziekan augustowski - ks. Jakub Choiński dokładnie spełniał obowiązki, prowadził nieposzlakowane życie. Dziekani pod opinią składali swój podpis i wyciskali pieczęć dziekańską. W 1825 r. w konsystorzu zestawiono na liście dwadzieścia nazwisk i przy nich podano opinie dziekanów. Oto kilka opinii. Ks. Wincenty Paszkiewicz - rozsądny gdy spokojny, zaś porywczy gdy rozgniewany, ks. Franciszek Zukowski - bogobojny, cnotliwy, nieobszernych wiadomości, ale rozsądny i umiarkowany, ks. Rafał Lasewicz - cnotliwej duszy i słodkiego charakteru, czytający zawsze i z korzyścią, statecznie cnotliwy i bardzo rozsądny. W $1828 \mathrm{r}$. do egzaminu przystępowali tylko wikariusze. W dwa lata potem bp Manugiewicz oznajmil, że nieodzownym warunkiem otrzymania beneficjum dla wszystkich księży jest złożenie egzaminu. Starsi księża, już proboszczowie, stronili od egzaminu publicznego. W 1835 r. bp Choromański przyznał, że przystąpienie do egzaminu razem $z$ młodymi jest dla nich upokorzeniem. Ale nie moźna inaczej, wymaga tego prawo kościelne i pilnuje rząd. Niechby egzaminatorzy potraktowali dziekanów „konfidencjonalnie". Gdyby jednak ich egzamin odbyl się nie wspólnie z młodymi, dano by okazję ludziom zazdrosnym, złośliwym i intrygantom. W tym roku kilku dziekanów i proboszczów zdawało egzamin publiczny ${ }^{32}$.

\subsection{Wprowadzenie proboszcza do parafii}

Kandydat na proboszcza miał przedstawić szereg dokumentów, m.in. opinię od dziekana. Księża zatrudnieni poza parafią dostarczali opinie od swoich bezpośrednich przełożonych, na przykład od rektora szkoły wojewódzkiej. Ostatnim etapem było objęcie beneficjum. Nowego proboszcza wprowadzał dziekan. Samo objęcie beneficjum miało uroczystą oprawę. W 1825 r. w święto Trzech Króli, przy dźwięku dzwonów, dziekan wprowadził do kościoła proboszcza parafii Romany. W dwa lata potem inny dziekan dokonal formalności kanonicznych przy obsadzaniu proboszcza w Dąbrówce.

\footnotetext{
${ }^{32}$ W. Jemielity, Konkursy na beneficja w Królestwie Polskim 1817-1865, Prawo Kanoniczne 38 (1995) nr 3-4, s. 215.
} 
W 1834 r. w Czyżewie dziekan wygłosił kazanie oraz z kollatorami i członkami dozoru kościelnego dokonał spisu inwentarza kościelnego. W 1842 r. w Kolakach dziekan przedstawił wiernym ważność i wielkość powołania kaplańskiego, wezwał parafian do szacunku i uległości dla nowego proboszcza jako namiestnika Chrystusowego, potem spisano protokół zdawczo-odbiorczy. W 1848 r. administrator diecezji dla dokonana introdukcji upoważnił jednego z pracowników konsystorza, ponieważ dziekan był chory. Ten sposób wchodzenia proboszcza do parafii obowiązywał i po powstaniu styczniowym. W 1877 r. ministerstwo spraw wewnętrznych określito porządek zdawania i przyjmowania parafii rzymskokatolickich. Zgodnie $\mathrm{z}$ artykułem dziewiętnastym ukazu z 14/26 grudnia $1865 \mathrm{r}$. objęcie parafii miało się to dokonywać w obecności dziekana i dozoru kościelnego ${ }^{33}$.

\subsection{Majątek parafialny po śmierci proboszcza}

Przy zmianie proboszcza kierowano się prawem kościelnym i rządowym, drugim głównie w odniesieniu do majątku parafialnego. W 1829 r. komisja rządowa podała szczegółowe wytyczne w tym względzie, m.in. że po śmierci proboszcza tymczasowy administrator obejmie probostwo w obecności dziekana lub jego zastępcy. Należy spisać cały inwentarz kościelny w trzech egzemplarzach. Odchodząc z parafii administrator złoży sprawozdanie za czas swojej pracy, a dziekan powiadomi o tym biskupa. W tymże 1829 r. komisja rządowa zwróciła się do biskupa, aby ten przypomniał dziekanom obowiązek odbywania periodycznych wizyt kościołów i sprawdzanie dokładnie inwentarza kościelnego. W 1834 r. bp Manugiewicz polecił dziekanom czuwać nad majątkiem parafialnym nie tylko podczas wizytacji. Jeżeli potem ujawnią się straty w tymże majątku, dziekani poniosą osobistą odpowiedzialność. W 1877 r. minister spraw wewnętrznych ogłosił przepisy względem przyjmowania i zdawania majątku kościelnego. Wprowadzenie proboszcza do zarządu parafią miało dokonywać się w obecności dziekana. Dziekan podpisywał protokól zdawczo-odbiorczy i rozstrzygał wszelkie spory między odchodzącym a przychodzącym do parafii duszpasterzem w sprawie

${ }^{33}$ W. Jemielity, Obsada stanowisk kościetnych w Królestwie Polskim do powstania styczniowego, s, 363, 373. 
wlasności parafialnej. Przepisy te obowiązywały do I wojny światowej ${ }^{34}$.

\subsection{Umowy między proboszczami i wikariuszami}

W diecezji augustowskiej czyli sejneńskiej było różne wynagrodzenie wikariuszy w części polskiej i w częśsi litewskiej. Ponadto przy braku jednolitego prawa o wynagrodzeniu proboszczowie dobierali sobie wikariuszy, bądź ci samowolnie opuszczali placówki. $\mathrm{Na}$ taką sytuację reagowała władza cywilna i kościelna. Wykonawcą ich poleceń był dziekan. W 1827 r. dziekan badal skargę proboszcza ze Słucza. Okazało się, że wikariusz nie spełniał swoich obowiązków; musiał on opuścić dotychczasowe miejsc pracy. W $1835 \mathrm{r}$. bp Choromański polecił za każdym razem spisywać umowę między proboszczem a wikariuszem. Gdy w 1837 r. w Radziłowie powstał konflikt między księżmi, głównie przez wtrącanie się siostry proboszcza, dziekan zapytał biskupa o możliwość odrębnego stolowania wikariusza. W 1840 r. proboszcz z Białaszewa przyjął pomocnika niechętnie i tłumacząc się ubóstwem parafii nie chciał zawrzeć umowy. Wikariusz zwrócił się o pomoc do dziekana. Przybył on do Białaszewa, ale stwierdzil, że trudno o zgodę między dwoma upartymi kaplanami. Dziekan odniósł się w tej sprawie do biskupa. W 1847 r. bp Straszyński polecil dziekanom naradzić się z proboszczami i przedstawić projekt do wydania stanowczego rozporządzenia w sprawie uposażenia wikariuszy. W 1849 r. administrator diecezji, ks. Mikołaj Błocki informował dziekanów, że wikariusze często skarżą się na proboszczów o zaleganie pensji, uszczuplanie dochodów iura stolae oraz innych oznaczonych i umówionych dodatków. Dlatego konieczne są umowy na piśmie, a nie tylko słowne. Dziekani niech mają to na uwadze. Po powstaniu styczniowym nie było uznanych przez rząd umów, ale faktycznie istniały one nadal. Gdy w 1882 r. proboszcz ze Słucza odmówił wikariuszowi części dochodów parafialnych, ten prosił biskupa o zmianę placówki. Sprawę badał dziekan ${ }^{35}$.

${ }^{34}$ W. Jemielity, Majatek parafialny przy zmianie i niedyspozycji proboszcza $w$ diecezji augustowskiej czyli sejneńskiej, Prawo Kanoniczne 47 (2004) nr 1-2, s. 132, 135, 139. ArEm, II sygn. 485 k. 22.

${ }^{35}$ W. Jemielity, Uposażenie i obowiąki wikariuszy $w$ diecezji augustowskiej czyli sejneńskiej, Prawo Kanoniczne 44 (2001) nr 1-2, s. 142, 148, 150, 155, 158. 


\subsection{Rezydencja duchownych}

W Królestwie Polskim rząd wydał szereg przepisów względem pozostawania duchownych w miejscu ich pracy. Również biskupi wypowiadali się w tej sprawie, raczej powodowani rozporządzeniami cywilnymi. Dnia 6/18 marca 1817 r. car Aleksander I podpisal ukaz o duchowieństwie rzymskokatolickim. Artykuł 16 ukazu stanowil, że duchowni nie mogli oddalać się od swych kościołów bez pozwolenia władzy duchownej. Ta udzielała pozwolenia na sześć tygodni, na dłużej komisja rządowa. W 1829 r. komisja rządowa wyjaśniła, że w nagłym przypadku proboszcz ma powiadomić dziekana o wyjeździe, by ten zaopiekował się parafią. W 1834 r. komisja rządowa przypomniała przepisy z $1817 \mathrm{r}$. W $1844 \mathrm{r}$. komisja ta zakazała wikariuszom oddalać się z domu bez wiedzy proboszcza i dziekana, którzy stawali się odpowiedzialni za postępowanie młodych księży. Ograniczenia wyjazdów z miejsca pracy nasiliły się po powstaniu styczniowym. Od 1870 r. dziekani mogli odbywać urzędowe podróże tylko w swoim dekanacie, zaś proboszczowie i wikariusze w swojej parafii. Na dalszy wyjazd wszyscy starali się o zezwolenie naczelnika powiatu. $\mathrm{W}$ osiem lat potem rząd pozwolit księżom udawać się do chorego na terenie innej parafii. Niezależnie od powielania przepisów rządowych, biskupi wydawali własne. W $1813 \mathrm{r}$. konsystorz wigierski ustosunkował się do zmian wikariuszy. Wikariusz najmniej miesiąc wcześniej miał uprzedzić dziekana o zmianie placówki, winien był podać przyczyny i wskazać miejsce przyszłej pracy. Wikariusz prosil swojego proboszcza o świadectwo za czas pobytu w parafii. Gdyby ten nie chciał wydać świadectwa, czynił to dziekan. Gdy wikariusz przechodził do innego dekanatu, również dziekan dawał o nim opinię do konsystorza. Jedynie dziekan móg1 dopuścić do ołtarza na kilka tygodni księży $\mathrm{z}$ innej diecezji. W 1844 r. bp Straszyński zobowiązał dziekanów, by jedynie dobrze znani księża świeccy lub zakonni zastępowali proboszcza w ich obowiązkach. Dziekan pozwalał księżom na sześciodniowy wyjazd. W 1865 r. konsystorz upoważnił proboszczów do udzielania wikariuszom pozwoleń na jedno- lub dwudniowy wyjazd w pobliskie miejsce. Dziekani mogli to uczynić dla proboszczów i wikariuszy na czas dłuższy niż 48 godzin, maksymalnie do dwóch tygodni. W 1880 r. dziekan pozwalał na wyjazd dwutygodniowy. Kapłani obejmujący nową placówkę mieli zawsze o tym powiadamiać dzie- 
kana. Po ukazie tolerancyjnym 1905 r. duchowni uzyskali więcej swobody przy oddalaniu się $\mathrm{z}$ parafii. W rok potem na konferencji dziekanów diecezji sejneńskiej uchwalono, że do podania o urlop zagraniczny należy dołączyć świadectwo dziekana i proboszcza ${ }^{36}$.

\subsection{Akta stanu cywilnego}

Urzędowa rejestracja urodzeń, ślubów i zgonów wywodzi się z praktyki kościelnej, istnieje od czasu soboru trydenckiego. Rewolucja Francuska powierzyła tę rejestrację urzędnikom świeckim. W Księstwie Warszawskim tzw. Kodeks Napoleona dotyczący tej sprawy obowiązywał od 1808 r. I tutaj początkowo byli urzędnicy świeccy, ale wkrótce obowiązkiem tym obciążono duchownych, a ustawowo na sejmie w 1825 r. Proboszczowie podlegali więc dwom władzom, duchownej i świeckiej. Wśród urzędników stanu cywilnego szczególną pozycję zajmowali dziekani. Po 1808 r. ich rola była jeszcze niewielka. W 1820 r. komisja rządowa zleciła dziekanom wgląd $w$ akta stanu cywilnego podczas dorocznych wizyt w parafiach. Mieli oni podpisywać akta metryczne kościelne a w cywilnych aktach jedynie kontrolować sposób ich prowadzenia; pełną kontrolę akt cywilnych przeprowadzali urzędnicy państwowi. Właściwym urzędnikiem stanu cywilnego stał się dziekan w oparciu o ustawę sejmową z 1825 r. Miał on przybyć do parafii, parafować księgi, na ostatniej stronie poświadczyć ile kart zawiera każda księga. W 1827 r. komisja rządowa wyjaśniła, że czynności te spełni dziekan przy corocznej zwyczajnej wizycie kościołów swojego dekanatu. Proboszczowie spisywali po dwie księgi urodzen, ślubów i zgonów. Jeden egzemplarz pozostawał w parafii, drugi każdego roku przekazywano urzędom hipotecznym, tzw. Sądom Pokoju. Po powstaniu styczniowym dziekani nadal kontrolowali księgi stanu cywilnego. Od 1876 r. również prezesi sądów pokoju corocznie przeprowadzali w parafiach nadzwyczajną rewizję tych ksiąg. Dziekani niejednokrotnie doświadczali przykrości z racji swojej funkcji. W 1845 r. komisja rządowa stwierdziła uchybienia w kilkunastu parafiach okręgu sejneńskiego, podobnie jak w wielu miejscach kraju. Winą za to obciążyła proboszczów i dziekanów. Ponieważ prawo

${ }^{36}$ W. Jemielity, Rezydencja duchownych w Królestwie Polskim, Prawo Kanoniczne 44 (2001) nr 3-4, s, 185, 194, 197; tenże, Wyjazdy księzy poza teren wlasnej rezydencji, Roczniki Humanistyczne 1973, t. 2, s. 265. 
krajowe nie przewidywało kar na dziekanów, komisja rządowa zamierzała zwrócić się do Rady Administracyjnej Królestwa, aby ta upoważniła sądy do wszczęcia procesów. Biskup sejneński Straszyński był temu przeciwny z następujących powodów: dziekani to duchowni cnotliwi i bardziej wykształceni. Księża ci unikali by podjęcia się funkcji dziekana $z$ obawy uchybienia w czymkolwiek licznym władzom mającym nadzór i w dodatku możność karania. Pensja dziekana jest uboga, prace rozliczne, sprawdzanie ksiąg nie wynika z powołania kaplańskiego. Dziekani są również proboszczami, mają dużo własnej pracy, nie mogą bezustannie jeździć po rozległych dekanatach i jedynie tylko pilnować zapisywania aktów. Stosowanie kary byłoby ujmą dla ludzi wykształconych, zwłaszcza że dziekani podjęli obowiązki dobrowolnie. W 1818 r. komisja rządowa wymagała od biskupów powiadamiania sądów pokoju i prokuratorów królewskich o każdej zmianie duchownego, który pełnił obowiązki urzędnika stanu cywilnego. Dziekani mieli spisywać protokół o stanie akt i przesyłać takowy do biura prokuratorskiego ${ }^{37}$.

\subsection{Przekazywanie wiadomości urzędowych}

Sposób przekazywania dokumentów, wiadomości z ośrodka władzy administracyjnej w teren nazywano kurrendą, cyrkularzem, obiegnikiem. Pisma pochodziły od cara, komisji rządowych, komisji wojewódzkich, burmistrzów, wójtów, a dotyczyły wielorakich spraw cywilnych. Były ponadto rozporządzenia biskupa, listy pasterskie, w ogóle pisma odnoszące się do spraw kościelnych. Rozporządzenia cywilne i kościelne przesylał do dziekanów zasadniczo biskup, wyjątkowo same wladze cywilne. Dziekan odpisywał dokument w specjalnej księdze i posłańcem przekazywal go do najbliższej parafii, ta do następnej, i pismo wracało do dziekana. On z kolei powiadamiał biskupa o spelnieniu polecenia a niekiedy zwracał i sam dokument. Większość tych ogłoszeń podawano wiernym z ambony, niektóre były ogłoszenia przeznaczone do wiadomości samych duchownych. W 1821 r. dziekani dwukrotnie ogłaszali zawieszenie księży w czynnościach kościelnych ${ }^{38}$.

\footnotetext{
${ }^{37}$ W. Jemielity, Akta stanu cywilnego w Kriestwie Warszawskim i Królestwie Polskim, Prawo Kanoniczne 38 (1995) nr 1-2, s. 168.

${ }^{38}$ W. Jemielity, Kurendy w Królestwie Polskim, Prawo Kanoniczne 39 (1996) nr 3-4, s. 238. Por. W Jemielity, Ambona w Kriestwie Warszawskim i Królestwie Polskim dla ogloszeń cywilnych, Prawo Kanoniczne 43 (2000) nr1-2, s. 147-221. ArLm, II sygn. 54 k. 5.
} 


\subsection{Przenoszenie wiosek do innych parafii}

Zmianie granic parafii podlegała władzy kościelnej i państwowej, drugiej szczególnie po powstaniu styczniowym. Wójt i naczelnik powiatu przesyłali podanie mieszkańców do gubernatora. Ten zawsze zwracal się do biskupa, by wypowiedzial się w tej sprawie. Biskup delegował dziekana, który przeprowadzał szczegółowe badania. Na przykład w 1872 r. dziekan udał się do parafii Syntowty i rozmawiał oddzielnie $\mathrm{z}$ każdym gospodarzem w siedmiu wioskach. W 1893 r. dziekan zatrzymał się w domu sołtysa wsi Racibory, odczytał mieszkańcom ich prośbę, obliczył ilość domów, sprawdził autentyczność podpisów, zbadał odległość do obu kościołów. W niektórych przypadkach występowali razem dziekan i naczelnik powiatu, wspólne badanie usuwało wiele trudności. W 1890 r. spotkali się razem dwaj dziekani i dwaj naczelnicy powiatu, ponieważ wsie przechodziły do parafii położonej w innym dekanacie i w innym powiecie ${ }^{39}$.

\subsection{Towarzyszenie biskupowi}

W 1821 r. biskup sejneński Czyżewski polecił przeczytać z ambon i przybić do drzwi kościoła swój list zapowiadający wizytację diecezji. W liście zaznaczył, że w każdej parafii mają na niego oczekiwać: miejscowi księża, dziekan, kollatorzy i wierni. W 1839 r. to samo pisal biskup sejneński Straszyński. Przy ustalaniu kolejności parafii mieli mu służyć pomocą dziekani. biskup prosił o pomoc dziekanów. Dziekan z Tykocina nawet wyrysował mapkę kościołów swojego i sąsiedniego dekanatu. W 1873 r. biskup sejneński Wierzbowski też wymagał obecności dziekana przy powitaniu w parafii, a zapewne czynili i jego następcy. Poszczególni biskupi na zwizytowanie parafii przeznaczali dwa do trzech dni i wyruszali do kolejnej parafii. Za biskupem podążali dziekani ${ }^{40}$.

\subsection{Dozory kościelne}

We wszystkich parafiach istniały „dozory kościelne”. Instytucję tę powołał i kontrolował rząd. Członkowie dozoru zajmowali się

\footnotetext{
${ }^{39}$ W. Jemielity, Przylaczanie wiosek do innych parafii w diecezji augustowskiej czyli sejneńskiej, Studia Teologiczne 13 (1995) s. 315; Por. tenże, Zmiana granic parafii w diecezji augustowskiej czyli sejneńskiej, Studia Teologiczne 18 (2000) 412-430.

${ }^{40}$ W. Jemielity, Wizytacje biskupie, (1999), s. 233, 235.
} 
utrzymaniem w dobrym stanie budynków kościelnych i cmentarzy. W skład dozoru wchodzili na sześć lat z urzędu: kollator, dziedzic i miejscowy dziekan oraz $\mathrm{z}$ wyboru trzech właścicieli nieruchomości. Członkowie dozorów kościelnych mieli corocznie w kwietniu sprawdzać zabudowania parafialne, zobowiązywać proboszcza do reperacji budowli i oznaczać termin zakończenia tych prac. W 1845 r. komisja rządowa zwróciła się do biskupów z prośbą, by dziekani przysyłali także naczelnikowi powiatu protokoły swoich urzędowych dziekańskich wizytacji w tym co dotyczyło budowli parafialnych. Pozwoli to porównać opinie dozorów kościelnych z opiniami samych dziekanów ${ }^{41}$.

\subsection{Szkoly}

W średniowieczu przy kościele parafialnym $z$ reguły znajdowała się szkoła. W 1215 r. sobór laterański nakazal utrzymywać nauczyciela przy każdym lepiej uposażonym kościele. W Polsce pierwsze wzmianki o szkołach parafialnych pojawily się w pierwszej połowie XIII wieku, w następnych stuleciach szkoła taka była zjawiskiem powszechnym. Całokształt szkolnictwa normowaly ustawy kościelne. Dopiero Komisja Edukacji Narodowej przejęła kontrolę państwową nad szkolnictwem. Jednak szkoły zwane elementarnymi lub parafialnymi nadal byly przy parafiach. Opiekunami szkól elementarnych byli proboszczowie, oni zbierali od parafian składki na utrzymanie szkoły i opiniowali pracę nauczyciela. W formularzach wizytacji dekanalnych były pytania o stan budynku, ile dzieci uczęszczało do szkoły, kto był nauczycielem, jak on pracowal i jak się zachowywał ${ }^{42}$. Po powstaniu styczniowym opieka nad szkołami przejęły gminy, dlatego w formularzach wizytacji dziekańskich nie pojawiało się zagadnienie szkół.

\section{Vicari foranei nella diocesi Wigry e Augustów cioe’ di Sejny}

La diocesi Wigry esistette negli anni 1799-1818, diocesi Augustów cioe' di Sejny dal 1818 fino alla I guerra mondiale. Ambedue furono divise in decanati. Vicario foraneo rappresentante del vescovo nel decanato. Nel Regno Polacco, anche il

${ }^{41}$ W. Jemielity, Dozory kościelne w Królestwie Polskim, Prawo Kanoniczne 36 (1993) nr 3-4, s. $173,175,180$.

${ }^{42}$ W. Jemielity, Parafialne szkoly elementarne w guberni augustowskiej (1815-1848), Rocznik Białostocki 12 (1974) s. 236, 241. 
potere civile decideva della sua nomina. Egli visitava le parocchie del decanato. I parrocci in iscritto rispondevano alle sue numerose domande. Esse riguardavano in maggioranza edifici ecclesiastici e parrocchiali, attrezzatura ecclesiastica, terreni apparteneti alla parrocchia e dei sacerdoti che svolgevano il compito pastorale. I moduli delle visite dei decani erano meno dettagliati che moduli delle visite dei vescovi. Queste invece in parte avevano simile contenuto come visite decanali; invece in modo dettagliato descrivevano la vita sacramentale e spirituale delle parrocchie. Dopo l'Insurrezzione di Gennaio 1863 nelle due categorie di visite non erano toccati problemi di proprieta' terrene e fondazioni della parrocchia perche furono passatte sotto il tesoro dallo stato. In modulo delle visite del vicario foraneo ufficialmente descriveva: opinione della vita personale del clero, introduzione di un nuovo parroco nella parrocchia, cura del beneficio parrocchiale dopo la morte del parrocco, conferma degli accordi tra il parroco e vicario, assicurazione di continuita' delle funzioni nella parrocchia nel caso di assenza del sacerdote, controllo dei libri delle metriche, consegna della corrispondenza e degli ordini del vescovo, accompagnamento al vescovo durante sua visita nel decanato, formazione dell' opinione nel caso di erezione di una nuova parrocchia oppure nel caso di spostamento dei villaggi da una parrocchia all'altra e cura delle scuole elementari. 